Seminário de Pesquisa

Programa de Pós-Graduação

Design FAU USP

\title{
Design para a atenção: técnicas projetuais de interfaces em Realidade Aumentada voltadas a educação informal
}

\author{
Diego Enéas Peres Ricca, Clice de Toledo Sanjar Mazzilli
}

\author{
design para a atenção; Teoria da Atividade; aprendizado informal; \\ realidade aumentada; realidade mista; projeção mapeada
}

Pesquisa relativa ao processo de projeto de capturar e reter a atenção humana no uso de interfaces digitais tangíveis em realidade aumentada voltada à educação informal. Foca-se no entendimento de como o design pode contribuir para tornar o uso desses artefatos crescentemente mais engajadores no aprendizado por meio de experiências relevantes, e não apenas vetores de entretenimento

Curso

Doutorado

\section{Linha de Pesquisa}

Design: Processos e Linguagens

\section{Diego Enéas Peres Ricca}

Arquiteto, Mestre e Doutorando em Design na FAU USP. Professor efetivo da UFC. Desenvolve investigações na área de Realidade Mista, especialmente Realidade Aumentada e projeção mapeada com ênfase na educação e no aspecto humano presente no processo de design de tais interfaces.

e-mail: diegoricca@usp.br Lattes: http://lattes.cnpq. $\mathrm{br} / 8251503092812059$

Orcid: https://orcid.org/00000002-5356-8041

\section{Clice de Toledo Sanjar Mazzilli}

Arquiteta e urbanista pela FAUUSP onde realizou mestrado, doutorado e livre-docência na área de Programação Visual. Tem experiência nas áreas de Design, Arquitetura e Arte nos temas: processos experimentais, linguagem visual, design do livro imagem, narrativas visuais, design de ambientes lúdicos.

e-mail: clice@usp.br

Lattes: http://lattes.cnpq. $\mathrm{br} / 9635315172253349$

Orcid: https://orcid.org/00000002-6903-9099 vazio e deslumbre fetichista tecnológico. Tem-se a hipótese que estudar aspectos subjetivos da atenção humana pode ser um caminho para entender tais estratégias projetuais. Será utilizada a Teoria da Atividade como framework teórico para análise de interações de usuários, dados estes que serão coletados por meio da técnica de videografia, somada a entrevistas com usuários. O termo Realidade Aumentada considera a junção de elementos virtuais associados ao ambiente físico, possuindo aplicações que consideram desde o uso de projeções interativas em tempo real (projector-based AR), até o de modo vestível ou visualizadas por smartphone. Considera-se em especial, a possibilidade tangível que esta tipologia de mídia dá ao usuário ao se vincular a objetos físicos por meios visuais ou auditivos. Dentro disso, adota-se métodos de pesquisa e análise de dados que tenham abordagens voltadas ao estudo do designer no processo de projeto, os quais intencionam produzir conhecimento a partir do ato de projetar e do ato de avaliar este processo - research-through-design (Zimmerman et al., 2007) e design-oriented research (Fallman, 2007). Tais métodos tratam, portanto, de uma tradução prática das questões levantadas na teoria, pela criação de exercícios e protótipos avaliados por meio de usos em contextos reais, a fim de compreender comportamentos ou experiências dos usuários. 


\title{
Design for attention: Augmented Reality interface design techniques aimed at informal education \\ Diego Enéas Peres Ricca, Clice de Toledo Sanjar Mazzilli
}

\author{
design for attention; Activity Theory; informal learning; augmented \\ reality; mixed reality; projection mapping
}

Research in the context of the design process of capturing and retaining human attention in the use of tangible digital interfaces in augmented reality aimed at informal education. It focuses on understanding how design can contribute to making the use of these artifacts increasingly engaging in learning through relevant experiences, and not just vectors of empty entertainment and technological fetishism. It has been hypothesized that studying subjective aspects of human attention can be a way to understand such design strategies. Activity Theory will be used as a theoretical framework for the analysis of user interactions, data that will be collected through the technique of videography plus interviews with users. The term augmented reality deals with a media typology that considers the combination of virtual elements associated with the

Course

Doctoral

\section{Line of Research}

Design: Processes and Languages

\section{Diego Enéas Peres Ricca}

Architect, Master and PhD student in Design at FAU USP. Effective professor at UFC. Develops research in the Mixed Reality area, especially Augmented Reality and mapped projection with an emphasis on education and the human aspect present in the design process of such interfaces. e-mail: diegoricca@usp.br Lattes: http://lattes.cnpq. $\mathrm{br} / 8251503092812059$

Orcid: https://orcid.org/00000002-5356-8041

\section{Clice de Toledo Sanjar Mazzilli}

Architect and urbanist at FAUUSP where completed a master's, doctorate and free teaching in the area of Visual Programming. Has experience in Design, Architecture and Art in the themes: experimental processes, visual language, image book design, visual narratives, design of playful environments.

e-mail: clice@usp.br

Lattes: http://lattes.cnpq. $\mathrm{br} / 9635315172253349$

Orcid: https://orcid.org/00000002-6903-9099 physical environment, this has varied applications that consider since the use of interactive projections in real time (projector-based AR), as well as wearable applications or viewed by smartphone. In particular, the tangible possibility that this type of media gives the user when linking to physical objects is considered, whether by visual or auditory means. Within this, research methods and data analysis are adopted considering approaches focused on the study of the designer in the design process, which intend to produce knowledge from the act of designing and the act of evaluating this process - research-through-design (Zimmerman et al., 2007) and design-oriented research (Fallman, 2007). Such methods, therefore, deal with a practical translation of the issues raised in the theory through the creation of exercises and prototypes evaluated through uses in real contexts, in order to understand users' behaviors or experiences.

\section{Referências | References}

BACCA, J. et al. 2014. Augmented reality trends in education: a systematic review of research and applications. Educational Technology \& Society, 17 (4): 133-149.

BAKKER, S. 2013. Design for peripheral interaction. Tese de Doutorado, Eindhoven University of Technology, Eindhoven.

KAPTELININ, V. \& NARDI, B. A. 2006. Acting with technology: Activity theory and interaction design. Cambridge: MIT Press.

LEONTIEV, A. N. 1978. Activity, consciousness, and personality. Englewood Cliffs: Prentice-Hall International.

VYGOTSKY, L. S. 1988. A formação social da mente brasileira. São Paulo: Martins. 